\title{
ANALISIS KETELITIAN GEOMETRIK CITRA SATELIT PLEIADES 1B DAN SPOT 6 UNTUK PEMBUATAN PETA DESA
}

\author{
Bangun Muljo Sukojo ${ }^{1}$, Iva Nurwauziyah ${ }^{1}$ \\ ${ }^{1}$ Departemen Teknik Geomatika, FTSLK-ITS, Kampus ITS Sukolilo, Surabaya, 60111, Indonesia \\ e-mail: ${ }^{1}$ bangun_ms@geodesy.its.ac.id
}

\begin{abstract}
Abstrak
Dalam penelitian ini, citra Pleiades 1B dan citra SPOT 6 dilakukan tinjau ulang sampai sejauh mana ketelitian geometrik terhadap kondisi sebenarnya yang akan digunakan sebagai sumber data untuk pembuatan peta desa dengan skala besar. Pada penelitian dilakukan proses rektifikasi dengan menggunakan data titik kontrol tanah (GCP) pada citra satelit Pleiades 1B dan SPOT 6 dengan menggunakan 2 metode yaitu polinomial orde 1 dan orde 2, selanjutnya dilakukan uji ketelitian geometrik pada hasil rektifikasi citra dengan data Independent Check Point (ICP) untuk mengetahui tingkat ketelitian horizontal berdasarkan PerKa BIG No. 15 Tahun 2014, sehingga dapat dilakukan analisis mengenai ketelitian horizontal citra untuk pembuatan peta desa.

Hasil yang diperoleh dari proses rektifikasi citra dengan 8 GCP diperoleh nilai rata-rata RMS metode polinomial orde 2 lebih baik daripada orde 1 yaitu 0,188 pixel pada citra Pleiades 1B dan 0,350 pixel pada citra SPOT 6. Berdasarkan uji ketelitian geometrik pada citra terkoreksi metode polinomial orde 1 didapatkan nilai RMSE pada citra Pleiades 1B adalah 0,806 meter dan pada citra SPOT 6 adalah 2,489 meter sedangkan pada citra terkoreksi metode polinomial orde 2 didapatkan nilai RMSE untuk citra Pleiades 1B adalah 0,647 meter dan 2,386 pada citra SPOT 6. Untuk kelayakan citra resolusi tinggi untuk pembuatan peta desa berdasarkan Spesifikasi Teknis Pembuatan Peta Desa Tahun 2016 oleh BIG, citra satelit Pleiades 1B memenuhi syarat pembuatan peta desa dengan skala 1:2.500, 1:5.000, 1:10.000, sedangkan pada citra satelit SPOT 6 memenuhi syarat untuk pembuatan peta desa dengan skala 1:10.000.
\end{abstract}

Kata Kunci: Peta Desa, Pleiades 1B, Polinomial Orde 1, Polinomial Orde 2, SPOT 6

\begin{abstract}
In this study, Pleiades $1 B$ and SPOT- 6 images can be reviewed the extent to which the geometric accuracy of the actual conditions that will be used as source data for making village map with a large scale. In research conducted process of rectification by using data of ground control points (GCP) on the satellite image Pleiades-1B and SPOT 6, which using two methods, namely polynomial order 1 and order 2, then test the accuracy of geometric on the results of rectification the image to determine the level of precision horizontal based on Perka BIG No. 15 of 2014 , so be analyzed the accuracy of horizontal imagery for making village map.

The results obtained from the process of image rectificaation with $8 \mathrm{GCP}, \mathrm{RMS}$ value obtained method of polynomial $2^{\text {nd }}$ orde is better than $1^{\text {st }}$ orde, i.e. 0,188 pixel on the Pleiades $1 B$ image and 0,350 pixel on the SPOT 6 image. Based on geometric accuracy testing obtained value of RMSE on the Pleiades 1B image is 0,801 meters and on the SPOT 6 imaage is 2,489 meters on the image of the results of the polynomial $1^{\text {st }}$ order rectification method and on the polynomial $2^{\text {nd }}$ order rectification method, RMSE values obtained for the image of the Pleiades $1 B$ is 0,647 meters and 2,386 meter for the SPOT 6. For the feasibility of high-resolution imagery for creating village maps based on Technical Specifications Mapping Village 2016 by BIG, Pleiades 1B image eligible cartography village with a scale of 1: 2500, 1: 5000, 1: 10.000, while on satellite images SPOT 6 meet requirements for the manufacture of a village map with a scale of 1: 10,000.
\end{abstract}

Keywords: Village Map, Pleiades 1B, Polynomial $1^{\text {st }}$ Order, Polinomial $2^{\text {nd }}$ Order, SPOT 6

\section{PENDAHULUAN}

Kelurahan Wonorejo merupakan salah satu wilayah yang masuk dalam wilayah konservasi Pamurbaya (Pantai Timur Surabaya), yang terletak pada koordinat $07^{\circ} 17^{\prime} 56,18^{\prime \prime}$ LS dan $07^{\circ} 19^{\prime} 15,92^{\prime \prime}$ LS serta $112^{\circ} 47^{\prime} 9,63^{\prime \prime}$ BT dan $112^{\circ} 50^{\prime} 43,8^{\prime \prime}$ BT. Luas wilayah kelurahan ini adalah 648,453 Ha. Di kelurahan Wonorejo ini, terdapat salah satu lokasi pariwisata utama kota Surabaya, yaitu ekowisata mangrove. Wilayah ini telah ditetapkan oleh pemerintah kota Surabaya sebagai area konservasi mangrove dengan tujuan agar kelestarian ekosistem mangrove tetap terjaga. Selain area konservasi mangrove, di kelurahan ini 
juga terdapat hewan dan tumbuhan lain yang membuat lokasi ini menjadi kawasan wisata (Putri, 2013). Dengan keberadaan area mangrove yang menjadi wilayah konservasi sekaligus pariwisata, diperlukan adanya informasi geospasial agar dapat mendukung pengelolaan area tersebut, serta dapat digunakan sebagai dasar perencanaan pengembangan kelurahan ini dan untuk mendukung program pembangunan nasional. Informasi geospasial ini dapat disajikan dalam bentuk peta desa (BIG, 2016b).

Peta desa merupakan peta tematik bersifat dasar yang berisi unsur dan informasi batas wilayah, infrastruktur transportasi, toponim, perairan, sarana prasarana, penutup lahan, dan penggunaan lahan yang disajikan dalam peta citra, peta sarana prasarana, serta peta penutup lahan, dan penggunaan lahan. Peta desa dapat digunakan oleh pemerintahan pusat dan daerah untuk merencanakan pembangunan nasional yang lebih menyeluruh dengan tingkat kedetailan informasi tingkat desa (BIG, 2016b).

Dengan dimilikinya peta desa maka aparat desa dapat mengetahui batas wilayah desa, mengidentifikasi, dan menginventarisasi potensi atau aset desa sebagai langkah awal untuk perencanaan pemberdayaan potensi yang dimiliki desa. Selain itu, dengan peta desa dapat diketahui pula hal-hal yang dapat menjadi kendala dalam upaya pemberdayaan potensi tersebut, sehingga dapat dilakukan langkah penyelesaiannya (Sadarviana et al. 2014). Berdasarkan Spesifikasi Teknis Penyajian Peta Desa Tahun 2016 oleh BIG, peta desa ini dapat disajikan pada skala 1:2.500, 1:5.000 dan 1:10.000 dengan sumber data foto udara atau citra satelit resolusi tinggi.

Penelitian ini, melakukan kajian penggunaan citra satelit resolusi tinggi yang merupakan hasil dari teknologi penginderaan jauh untuk pembuatan peta desa berdasarkan Spesifikasi Teknis Penyajian Peta Desa Tahun 2016 oleh BIG. Perkembangan teknologi penginderaan jauh saat ini mengalami kemajuan yang signifikan, salah satunya adalah bertambah baiknya resolusi spasial yang dimiliki oleh citra. Resolusi spasial merupakan ukuran objek terkecil yang masih dapat disajikan atau dibedakan dan dikenali pada citra. Resolusi spasial mencerminkan seberapa rinci suatu sensor yang dipasang pada satelit dapat merekam suatu objek di permukaan Bumi secara terpisah. Semakin besar nilai resolusi spasial yang dimiliki, maka informasi objek yang ditampilkan pada data penginderaan jauh akan terlihat semakin rinci. Kerincian informasi atas suatu objek yang divisualisasikan pada data penginderaan jauh akan memudahkan operator dalam melakukan proses identifikasi suatu objek secara detail. Hal inilah yang menjadi salah satu pertimbangan penggunaan produk citra satelit banyak dimanfaatkan untuk pembuatan peta skala besar (Rudianto, 2010).

Namun, pemanfaatan teknologi penginderaan jauh untuk pemetaan skala besar masih memiliki beberapa kendala, misalnya perekaman data oleh sensor satelit yang tidak dapat digunakan secara langsung karena masih terdapat beberapa kesalahan geometrik yang harus dieliminasi. Oleh karena itu, diperlukan kajian ilmiah yang mengungkapkan seberapa jauh ketelitian geometrik citra terhadap kondisi sebenarnya sehingga hasil akhir yang diperoleh dapat dipertanggungjawabkan. Berdasarkan data, citra resolusi tinggi Pleiades $1 \mathrm{~B}$ dan SPOT 6 yang digunakan sebagai bahan penelitian. Citra Pleiades $1 \mathrm{~B}$ dengan resolusi spasial pankromatik $0,5 \mathrm{~m}$ dan multispektral $2 \mathrm{~m}$ serta citra SPOT-6 dengan resolusi spasial pankromatik $1,5 \mathrm{~m}$ dan multispektral $6 \mathrm{~m}$ dilakukan tinjau ulang sampai sejauh mana ketelitian geometrik terhadap kondisi sebenarnya di lapangan, yang nantinya digunakan sebagai sumber data untuk pembuatan peta desa.

\section{METODOLOGI PENELITIAN}

Lokasi penelitian ini dilakukan di wilayah kelurahan Wonorejo, kecamatan Rungkut, Surabaya yang terletak diantara koordinat $07^{\circ} 17^{\prime} 56,18^{\prime \prime}$ LS dan $07^{\circ} 19^{\prime} 15,92^{\prime \prime}$ LS serta $112^{\circ} 47^{\prime} 9,63^{\prime \prime}$ BT dan $112^{\circ} 50^{\prime} 43,8^{\prime \prime}$ BT.

Secara administratif kelurahan Wonorejo ini memiliki luas wilayah sebesar 648,453 $\mathrm{Ha}$ dan berikut adalah batas wilayah kelurahan Wonorejo:

Sebelah utara : Kelurahan Keputih

Sebelah timur : Selat Madura

Sebelah selatan : Kelurahan Medokan Ayu

Sebelah barat : Kelurahan Penjaringansari 


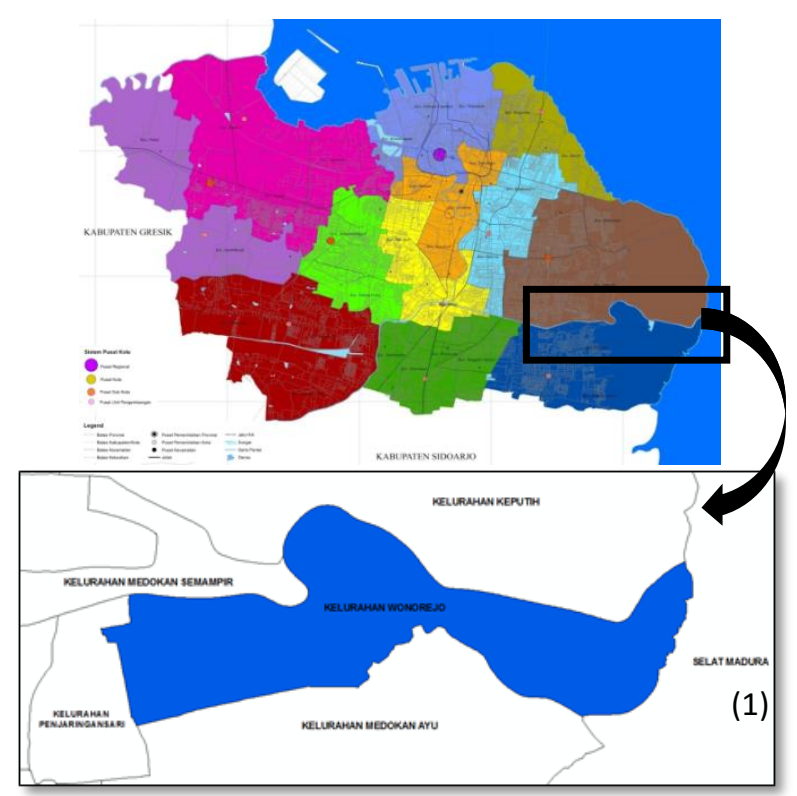

Gambar 1. Lokasi Penelitian

Tahapan pengolahan data pada penelitian ini digambarkan dalam diagram alir berikut ini:

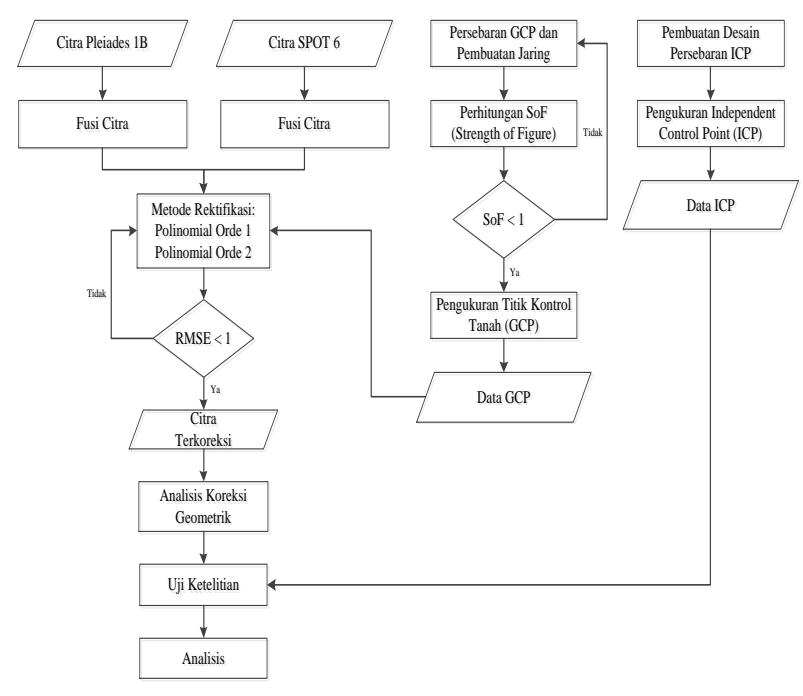

Gambar 2. Diagram Alir Pengolahan Data

Langkah pertama yang dilakukan pada penelitian ini adalah penggabungan (fusi) citra multispektral dan pankromatik menggunakan software pengolah citra, yang bertujuan memperoleh resolusi spektral dan kedetailan informasi spasial yang tinggi sehingga mudah untuk diilakukan interpretasi secara manual.

Langkah selanjutnya adalah pembuatan desain jaring. Pembuatan jaring yaitu pendistribusian secara merata di seluruh wilayah studi dari titik koordinat atau titik GCP yang nantinya akan mempengaruhi hasil koreksi geometrik. Distribusi titik yang baik dapat dilihat dari kekuatan jaring yang ditunjukkan dengan nilai SoF (Strength of Figure). Perhitungan SoF (Strength of Figure) dimaksudkan untuk mengetahui tingkat kekuatan geometri dari rangkaian segitiga yang menentukan penyebaran kesalahan dalam perataan jaringan. Hasil perhitungan SoF (Strength of Figure) yang diterima adalah $\leq 1$. Jika kesalahan lebih besar dari persyaratan maka penentuan titik-titik koordinat dan bentuk jaring pada citra dilakukan cek ulang. Rumus perrhitungan SoF dengan menggunakan metode parameter adalah sebagai berikut (Anjasmara, 2005):

Faktor Kekuatan Jaring $=\frac{\operatorname{Trace}\left(A^{\underline{T}} A\right)^{-1}}{u}$

Dimana, $\mathrm{A}$ adalah matriks desain dan $\mathrm{u}$ adalah nilai ukuran lebih (redundancy) yang diperoleh dari jumlah ukuran dikurangi jumlah parameter. Dalam hal ini, semakin kecil bilangan faktor kekuatan jaringan tersebut, maka akan semakin baik konfigurasi jaringan yang bersangkutan, dan sebaliknya.

Selanjutnya dilakukan pengukuran titik kontrol tanah (GCP) dan titik uji (ICP) dengan menggunakan alat GPS Topcon Hiper Pro. Setelah itu adalah koreksi geometrik. Koreksi geometrik dilakukan karena terjadi distorsi geometrik antara citra hasil penginderaan dan objeknya. Distorsi geometrik adalah ketidaksempurnaan geometri citra yang terekam pada saat pencitraan, hal ini menyebabkan ukuran, posisi, dan bentuk citra menjadi tidak sesuai dengan kondisi sebenarnya. Distorsi geometrik ini harus dikoreksi dahulu sebelum citra digunakan. Pada penelitian ini, melakukan koreksi distorsi geometrik dengan menggunakan titik kontrol tanah (GCP). Posisi titik kontrol tanah ditentukan dari beberapa objek yang mudah diidentifikasi pada citra, sehingga diperoleh koordinat dalam sistem koordinat tanah $(X, Y)$ dan dalam sistem koordinat citra $(x, y)$ (sebagai titik sekutu). Koreksi geometrik pada penelitian ini digunakan dua metode, yaitu polinomial orde 1 dan orde 2. Akurasi dari koreksi geometrik ditunjukkan dengan nilai RMS (Rate Mean Square) per unit pixel pada citra. Akurasi seharusnya $\leq 1$ pixel, apabila kesalahan lebih besar dari persyaratan, maka kembali melakukan koreksi geometrik.

Setelah itu dilakukan analisis ketelitian geometrik pada citra Pleiades 1B dan SPOT 6 terkoreksi 
dengan titik uji (ICP) berdasarkan pada nilai RMSE dan Circular Error (CE90)/tingkat ketelitian horizontal, sehingga dapat diketahui ketelitian geometrik pada citra Pleiades 1B dan SPOT 6 terhadap kondisi sebenarnya dan juga dapat dilakukan analisis kelayakan citra satelit resolusi tinggi sebagai dasar untuk pembuatan peta desa.

\section{HASIL DAN PEMBAHASAN}

\section{Hasil Fusi Citra}

Penggabungan citra multispektral resolusi rendah dan citra pankromatik resolusi tinggi merupakan hal yang sangat penting bagi aplikasi penginderaan jauh dan pemetaan. Citra pankromatik memiliki panjang gelombang yang luas mulai dari spektrum tampak dan inframerah dekat, sedangkan citra multispektral hanya mencakup spektrum yang sempit. Akan tetapi, citra multispektral memiliki jumlah lebih dari tiga spektral band, sedangkan citra pankromatik hanya memiliki satu spektral band saja. Sehingga dengan menggabungkan kedua citra tersebut maka diperoleh citra multispektral yang memiliki resolusi spektral yang tinggi dan kedetailan informasi spasial yang tinggi pula. Berikut adalah hasil fusi citra Pleiades 1B dan SPOT 6:

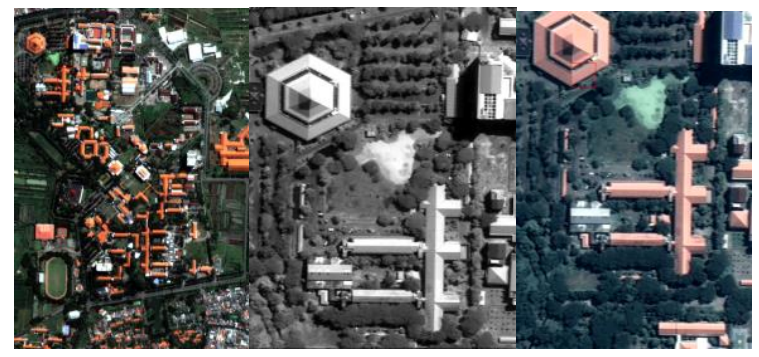

(a) 0

(b)

(c) 0

Gambar 3. (a) Citra Multispektral Pleiades 1B (b) Citra Pankromatik Peliades 1B (c) Hasil Fusi Citra Pleiades 1B

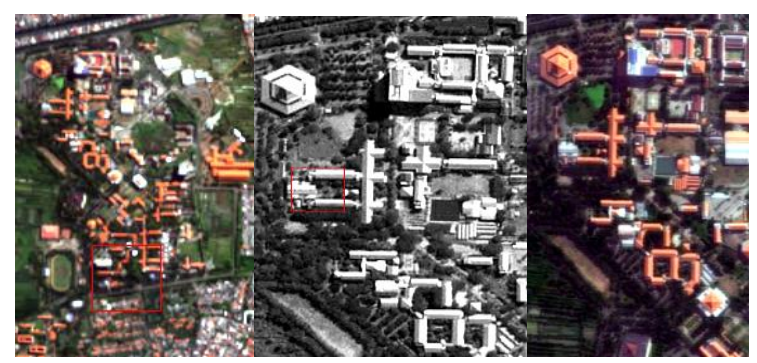

Gambar 4. Hasil Fusi Citra SPOT-6 (Penggabungan Citra Multispektral dan Pankromatik)
Hasil Pembuatan Jaring dan Perhitungan SoF

Dalam perencanaan proses rektifikasi citra dibutuhkan jumlah titik kontrol tanah yang tepat, agar pelaksanaan pengukuran di lapangan tidak terlalu lama (Yudha, 2015). Pada penelitian ini, jumlah GCP yang digunakan adalah 8 titik. Berikut adalah persebaran titik GCP:

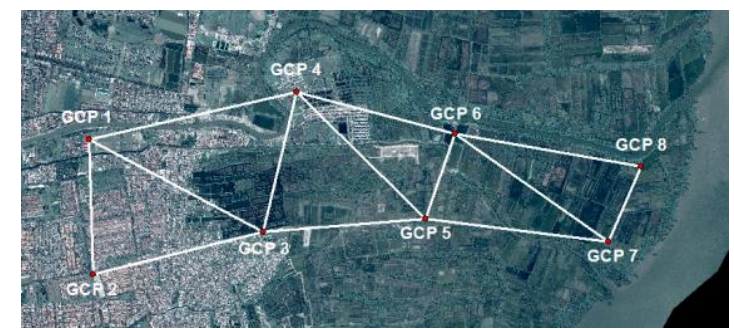

Gambar 5. Persebaran GCP dan Desain Jaring

Dengan desain jaring seperti pada gambar 5 . diperoleh nilai SoF (Strength Of Figure) adaalah 0.5938, dapat dikatakan jika perhitungan SoF memenuhi toleransi yaitu $\leq 1$. Dalam hal ini, faktor kekuatan jaring nilai yang semakin kecil maka akan semakin baik konfigurasi jaringan yang bersangkutan dan sebaliknya (Anjasmara, 2005).

\section{Hasil Pengukuran GCP dan ICP}

GCP dan ICP diukur di lapangan menggunakan alat GPS Topcon Hiper Pro. GCP diukur dengan metode static dengan pengamatan selama 45 menit sedangkan ICP diukur dengan metode rapid static. Berikut adalah hasil koordinat yang diperoleh dari pengukuran lapangan.

Tabel 1. Data Koordinat Hasil Pengukuran GCP

\begin{tabular}{ccc}
\hline \multirow{2}{*}{ Titik } & \multicolumn{2}{c}{ GROUND CONTROL POINT } \\
\cline { 2 - 3 } & $\mathbf{X}(\mathbf{m})$ & $\mathbf{Y}(\mathbf{m})$ \\
\hline GCP 1 & 697694.529 & 9191696.257 \\
GCP 2 & 697740.773 & 9190389.810 \\
GCP 3 & 699407.414 & 9190800.332 \\
GCP 4 & 699721.094 & 9192151.699 \\
GCP 5 & 701088.897 & 9190613.219 \\
GCP 6 & 701281.548 & 9191748.465 \\
GCP 7 & 702795.570 & 9190703.690 \\
GCP 8 & 703107.998 & 9191437.327 \\
\hline
\end{tabular}


Tabel 2. Data Koordinat Hasil Pengukuran ICP

\begin{tabular}{ccc}
\hline \multirow{2}{*}{ Titik } & \multicolumn{2}{c}{ INDEPENDENT CHECK POINT } \\
\cline { 2 - 3 } & $\mathbf{I C P})$ \\
\hline ICP 1 & 697911,493 & $\mathbf{Y}(\mathbf{m})$ \\
ICP 2 & 698867,089 & 9190670,503 \\
ICP 3 & 699812,476 & 9190861,748 \\
ICP 4 & 700801,105 & 919092,260 \\
ICP 5 & 701461,131 & 9190963,203 \\
ICP 6 & 702220,809 & 9190787,287 \\
ICP 7 & 702887,550 & 9191368,168 \\
ICP 8 & 702118,056 & 9191249,111 \\
ICP 9 & 701042,913 & 9191675,572 \\
ICP 10 & 699612,522 & 9191669,395 \\
ICP 11 & 698044,366 & 9191413,773 \\
ICP 12 & 697546,610 & 9190950,773 \\
\hline
\end{tabular}

Data hasil pengukuran pada Tabel 1 dan 2. hasil pengukuran lapangan yang diproses secara post processing dengan menggunakan perangkat lunak Topcon Tools v.7.5.1.

\section{Hasil Koreksi Geometrik}

Koreksi geometrik bertujuan untuk mereduksi terjadinya distorsi geometrik pada citra. Ada beberapa cara untuk melakukan koreksi geometrik, yaitu rektifikasi dan registrasi geometric (Afifi, 2015). Rektifikasi citra adalah suatu proses untuk memproyeksikan citra ke bidang datar dan menjadikannya bentuk konform (sebangun) dengan sistem proyeksi yang digunakan, juga memproyeksikan citra yang ada sehingga mempunyai arah yang benar (Setiadi)

Hal yang harus diperhatikan saat melakukan rektifikasi adalah pada saat penentuan titik-titik GCP pada citra, diusahakan titik-titik yang akan ditentukan pada citra sesuai dengan titik-titik yang diukur di lapangan sehingga akan didapatkan nilai kesalahan GCP minimum.

Proses rektifikasi menggunakan polinomial orde 1 dan orde 2. Pada polinomial orde 1 minimal dibutuhkan 3 GCP dan untuk polinomial orde 2 minimal dibutuhkan $6 \mathrm{GCP}$, sedangkan untuk polinomial orde 3 dibutuhkan minimal 10 GCP. GCP yang akan digunakan pada penelitian ini adalah $8 \mathrm{GCP}$, sehingga yang paling sesuai adalah metode polinomial orde 1 dan orde 2 .

Selain jumlah titik kontrol yang tersedia, terdapat juga faktor lain yang mempengaruhi pemilihan orde, diantaranya yaitu keadaan topografi daerah serta kesalahan atau distorsi pada citra yang akan dilakukan (Yudha, 2015). Berdasarkan hasil survei lapangan, topografi wilayah kelurahan wonorejo relatif datar dan berada di wilayah pesisir yang sebagian besar wilayahnya berupa tambak.

Berikut adalah koordinat titik kontrol pada citra satelit Pleiades 1B dan SPOT 6 yang akan digunakan untuk proses tranformasi pada saat dilakukannya koreksi geometrik:

Tabel 3. Data Koordinat Citra Pleiades 1B

\begin{tabular}{ccc}
\hline \multirow{2}{*}{ Titik } & \multicolumn{2}{c}{ TITIK KONTROL } \\
\cline { 2 - 3 } & $\mathbf{X}$ (Pixel) & Y (Pixel) \\
\hline GCP 1 & 15133,5 & 32135,0 \\
GCP 2 & 15237,0 & 34758,5 \\
GCP 3 & 18554,5 & 33906,0 \\
GCP 4 & 19168,0 & 31186,0 \\
GCP 5 & 21906,5 & 34254,0 \\
GCP 6 & 22280,0 & 31970,0 \\
GCP 7 & 25306,0 & 34042,5 \\
GCP 8 & 25922,5 & 32563,5 \\
\hline
\end{tabular}

Tabel 3. Data Koordinat Citra SPOT 6

\begin{tabular}{ccc}
\hline \multirow{2}{*}{ Titik } & \multicolumn{2}{c}{ TITIK KONTROL } \\
\cline { 2 - 3 } & $\mathbf{X}$ (Pixel) & Y (Pixel) \\
\hline GCP 1 & 6432 & 3600 \\
GCP 2 & 6465 & 4449 \\
GCP 3 & 7550 & 4179 \\
GCP 4 & 7750 & 3298 \\
GCP 5 & 8646 & 4295 \\
GCP 6 & 8769 & 3556 \\
GCP 7 & 9759 & 4231 \\
GCP 8 & 9961 & 3754 \\
\hline
\end{tabular}

Untuk mengetahui akurasi dari hasil rektifikasi citra, dapat diketahui dari nilai RMS (Rate Mean Square) per unit pixel pada citra. RMS menunjukkan derajat kesalahan dengan membandingkan koordinat GCP hasil hitungan dengan koordinat citra yang sebenarnya. Berikut adalah hasil dari proses rektifikasi citra Pleiades 1B dan SPOT 6 dengan metode polinomial orde 1 dan orde 2: 


\begin{tabular}{ccc}
\hline \multirow{2}{*}{$\begin{array}{c}\text { Tabel 4. Nilai RMSE Hasil Koreksi Geometrik Citra } \\
\text { Pleiades 1B dengan 8 GCP }\end{array}$} \\
\cline { 2 - 3 } Titik & \multicolumn{2}{c}{ RMS (Pixel) } \\
\hline & $\begin{array}{c}\text { Polinomial } \\
\text { Orde 1 }\end{array}$ & $\begin{array}{c}\text { Polinomial } \\
\text { Orde 2 }\end{array}$ \\
\hline GCP 1 & 0,328 & 0,231 \\
GCP 2 & 0,309 & 0,136 \\
GCP 3 & 0,293 & 0,173 \\
GCP 4 & 0,215 & 0,143 \\
GCP 5 & 0,524 & 0,218 \\
GCP 6 & 0,205 & 0,151 \\
GCP 7 & 0,344 & 0,215 \\
GCP 8 & 0,356 & 0,242 \\
Jumlah & $\mathbf{2 , 5 7 5}$ & $\mathbf{1 , 5 0 8}$ \\
Rata-Rata RMS (Pixel) & $\mathbf{0 , 3 2 2}$ & $\mathbf{0 , 1 8 8}$ \\
\hline
\end{tabular}

Tabel 5. Nilai RMSE Hasil Koreksi Geometrik Citra SPOT 6 dengan 8 GCP

\begin{tabular}{ccc}
\hline \multirow{2}{*}{ Titik } & \multicolumn{2}{c}{ RMS (Pixel) } \\
\cline { 2 - 3 } & $\begin{array}{c}\text { Polinomial } \\
\text { Orde 1 }\end{array}$ & $\begin{array}{c}\text { Polinomial } \\
\text { Orde 2 }\end{array}$ \\
\hline GCP 1 & 0,777 & 0,325 \\
GCP 2 & 0,570 & 0,462 \\
GCP 3 & 0,795 & 0,630 \\
GCP 4 & 0,685 & 0,392 \\
GCP 5 & 0,777 & 0,138 \\
GCP 6 & 0,296 & 0,260 \\
GCP 7 & 0,499 & 0,286 \\
GCP 8 & 0,672 & 0,310 \\
Jumlah & $\mathbf{5 , 0 6 9}$ & $\mathbf{2 , 8 0 2}$ \\
Rata-Rata RMS (Pixel) & $\mathbf{0 , 6 3 4}$ & $\mathbf{0 , 3 5 0}$ \\
\hline
\end{tabular}

Berdasarkan Tabel. didapatkan rata-rata nilai RMS untuk citra Pleiades $1 \mathrm{~B}$ dengan $8 \mathrm{GCP}$ adalah 0,322 pixel untuk metode polinomial orde 1 dan 0,188 pixel untuk metode polinomial orde 2 . Sedangkan pada citra SPOT 6 didapatkan rata-rata nilai RMS 0,634 pixel untuk metode polinomial orde 1 dan 0,350 pixel untuk metode polinomial orde 2. Jadi, proses rektifikasi citra Pleiades 1B dan SPOT 6 dapat diterima karena memenuhi toleransi yang diberikan yaitu $\leq 1$ sebagaimana disarankan.

Nilai RMSE metode rektifikasi citra yang bagus pada penelitian ini adalah metode polinomial orde 2, dimana rata-rata nilai RMS nya lebih kecil daripada metode polinomial orde 1 . Hal ini dikarenakan metode polinomial orde 2 dengan 12 parameter merupakan pengembangan dari metode polinomial orde 1 dengan 6 parameter (Mohammed,

\section{Hasil Uji Ketelitian Geometri}

Uji ketelitian geometri dilakukan dengan menggunakan titik Independent Check Point (ICP) yang berupa koordinat $(x, y)$ hasil pengukuran langsung di lapangan. Jumlah titik ICP yang digunakan adalah 12 titik.

Uji ketelitian geometri ini dilakukan untuk mengetahui nilai ketelitian citra satelit yang telah terkoreksi. Pengujian ketelitian posisi mengacu pada perbedaan koordinat $(x, y)$ antara titik uji pada citra dengan lokasi sesungguhnya dari titik uji pada permukaan tanah, yang nantinya akan didapatkan pergeseran titik (residu). Dari hasil residu tersebut, digunakan untuk menghitung nilai RMSE koordinat citra.

Tabel 6. Hasil Uji Ketelitian Geometrik Citra Satelit Pleiades 1B Hasil Rektifikasi Metode Polinomial Orde 1

\begin{tabular}{ccc}
\hline & \multicolumn{2}{c}{$\begin{array}{c}\text { Citra Hasil Rektifikasi } \\
\text { Polinomial Orde 1 }\end{array}$} \\
\cline { 2 - 3 } TITIK & $\begin{array}{c}\text { Residu X } \\
\text { (m) }\end{array}$ & $\begin{array}{c}\text { Residu Y } \\
\text { (m) }\end{array}$ \\
\hline ICP 1 & 0,310 & 0,573 \\
ICP 2 & 0,285 & 0,243 \\
ICP 3 & 0,177 & 0,126 \\
ICP 4 & 0,562 & 0,874 \\
ICP 5 & 0,650 & 0,447 \\
ICP 6 & 1,501 & 0,727 \\
ICP 7 & 1,068 & 0,343 \\
ICP 8 & 0,002 & 0,752 \\
ICP 9 & 0,079 & 0,089 \\
ICP 10 & 0,187 & 0,064 \\
ICP 12 & 0,482 & 0,169 \\
ICP 13 & 0,681 & 0,301 \\
RMSE (m) & \multicolumn{2}{|c|}{$\mathbf{0 , 8 0 6}$} \\
\hline
\end{tabular}

Tabel 7. Hasil Uji Ketelitian Geometrik Citra Satelit Pleiades 1B Hasil Rektifikasi Metode Polinomial Orde 2

\begin{tabular}{ccc}
\hline & \multicolumn{2}{c}{$\begin{array}{c}\text { Citra Hasil Rektifikasi } \\
\text { Polinomial Orde 2 }\end{array}$} \\
\cline { 2 - 3 } TITIK & $\begin{array}{c}\text { Residu X } \\
(\mathbf{m})\end{array}$ & $\begin{array}{c}\text { Residu Y } \\
(\mathbf{m})\end{array}$ \\
\hline ICP 1 & 0,393 & 0,479 \\
ICP 2 & 0,263 & 0,236 \\
ICP 3 & 0,366 & 0,305 \\
ICP 4 & 0,265 & 0,815 \\
ICP 5 & 0,130 & 0,130 \\
ICP 6 & 0,623 & 0,286 \\
ICP 7 & 1,032 & 0,212 \\
ICP 8 & 0,134 & 0,436 \\
ICP 9 & 0,372 & 0,008
\end{tabular}




\begin{tabular}{|c|c|c|}
\hline ICP 10 & 0,303 & 0,057 \\
\hline ICP 12 & 0,505 & 0,175 \\
\hline ICP 13 & 0,656 & 0,885 \\
\hline RMSE (m) & \multicolumn{2}{|c|}{0,647} \\
\hline \multicolumn{3}{|c|}{$\begin{array}{l}\text { Tabel 8. Hasil Uji Ketelitian Geometrik Citra Sa } \\
\text { SPOT } 6 \text { Hasil Rektifikasi Metode Polinomial Or }\end{array}$} \\
\hline \multirow{2}{*}{ TITIK } & \multicolumn{2}{|c|}{$\begin{array}{l}\text { Citra Hasil Rektifikasi } \\
\text { Polinomial Orde } 2 \\
\end{array}$} \\
\hline & $\begin{array}{l}\text { Residu X } \\
(\mathrm{m})\end{array}$ & $\begin{array}{c}\text { Residu Y } \\
(\mathrm{m})\end{array}$ \\
\hline ICP 1 & 0,916 & 1,772 \\
\hline ICP 2 & 1,672 & 1,797 \\
\hline ICP 3 & 2,945 & 1,474 \\
\hline ICP 4 & 1,804 & 2,593 \\
\hline ICP 5 & 0,727 & 0,331 \\
\hline ICP 6 & 0,056 & 1,930 \\
\hline ICP 7 & 2,238 & 1,930 \\
\hline ICP 8 & 2,939 & 1,091 \\
\hline ICP 9 & 0,997 & 0,178 \\
\hline ICP 10 & 0,750 & 2,036 \\
\hline ICP 12 & 3,041 & 0,860 \\
\hline ICP 13 & 0,975 & 1,972 \\
\hline RMSE (m) & \multicolumn{2}{|c|}{2,489} \\
\hline
\end{tabular}

Tabel 9. Hasil Uji Ketelitian Geometrik Citra Satelit SPOT 6 Hasil Rektifikasi Metode Polinomial Orde 2

\begin{tabular}{ccc}
\hline & \multicolumn{2}{c}{$\begin{array}{c}\text { Citra Hasil Rektifikasi } \\
\text { Polinomial Orde 2 }\end{array}$} \\
\cline { 2 - 3 } TITIK & $\begin{array}{c}\text { Residu X } \\
\text { (m) }\end{array}$ & $\begin{array}{c}\text { Residu Y } \\
\text { (m) }\end{array}$ \\
\hline ICP 1 & 0,674 & 1,803 \\
ICP 2 & 1,672 & 1,818 \\
ICP 3 & 2,813 & 1,342 \\
ICP 4 & 0,215 & 2,063 \\
ICP 5 & 0,516 & 0,749 \\
ICP 6 & 0,056 & 1,963 \\
ICP 7 & 0,572 & 2,921 \\
ICP 8 & 2,944 & 1,096 \\
ICP 9 & 2,521 & 0,157 \\
ICP 10 & 0,814 & 1,664 \\
ICP 12 & 3,041 & 0,847 \\
ICP 13 & 1,055 & 0,464 \\
RMSE (m) & \multicolumn{2}{c}{$\mathbf{2 , 3 8 6}$} \\
\hline
\end{tabular}

Berdasarkan hasil perhitungan uji ketelitian geometrik pada citra satelit pada Tabel, nilai RMSE pada citra Pleiades 1B lebih bagus daripada citra SPOT 6. Nilai RMSE pada citra Pleiades 1B lebih kecil daripada SPOT 6. Hal ini dikarenakan resolusi spasial pada citra Pleiades $1 \mathrm{~B}$ lebih bagus yaitu 0,5 meter dari pada citra SPOT 6 yaitu 1,5 meter, sehingga pada citra Pleiades 1B lebih mudah untuk mengidentifikasi letak titik kontrol tanah. Dan hasil RMSE uji ketelitian geometrik pada metode polinomial orde 2 lebih bagus yaitu mendekati nol daripada metode polinomial orde 1 , hal ini dikarenakan rata-rata RMS hasil rektifikasi pada metode polinomial orde 2 lebih baik (Mohammed, 2013).

\section{Analisis Ketelitian Geometri}

Menurut Perka BIG Nomor 15 Tahun 2014, ketentuan ketelitian geometri horizontal untuk pembuatan peta desa adalah:

Tabel 10. Ketelitian Horizontal Peta Desa

\begin{tabular}{ccccc}
\hline \multirow{2}{*}{ No. } & \multirow{2}{*}{ Skala } & \multicolumn{3}{c}{ (CE90 dalam m) } \\
\cline { 3 - 5 } & & Kelas 1 & Kelas 2 & Kelas 3 \\
\hline 1 & $1: 10.000$ & 2 & 3 & 5 \\
2 & $1: 5.000$ & 1 & 1,5 & 2,5 \\
3 & $1: 2.500$ & 0,5 & 0,75 & 1,25 \\
\hline
\end{tabular}

Nilai CE90 diperoleh dengan rumus berikut:

$$
\mathrm{CE} 90=1,5175 \times \mathrm{RMSE}
$$

Berdasarkan Tabel 7. maka citra satelit resolusi tinggi yang digunakan untuk pembuatan peta desa dikatakan memenuhi standar ketelitian peta desa apabila akurasi horizontal $\leq 5$ meter (kelas 3 ).

Tabel 11. Hasil Perhitungan Akurasi Horizontal pada Citra Satelit Pleiades 1B

\begin{tabular}{ccc}
\hline \multirow{3}{*}{ Hasil Perhitungan } & \multicolumn{2}{c}{$\begin{array}{c}\text { AKURASI HORIZONTAL }(\mathbf{m}) \\
\text { (CE90 }=\mathbf{1 , 5 1 7 5} \times \text { RMSE) }\end{array}$} \\
\cline { 2 - 3 } & $\begin{array}{c}\text { Polinomial } \\
\text { Orde 1 }\end{array}$ & $\begin{array}{c}\text { Polinomial } \\
\text { Orde 2 }\end{array}$ \\
\hline PLEIADES 1B & 1,222 & 0,982 \\
SPOT 6 & 3,776 & 3,621 \\
\hline
\end{tabular}

Maka, berdasarkan perkalian nilai RMSE dengan koefesien ketelitian $(1,5175)$ diperoleh ketelitian horizontal pada citra Pleiades 1B terkoreksi metode polinomial $1 \mathrm{~B}$ adalah 1,222 meter sedangkan pada pada metode polinomial orde 2 didapatkan akurasi horizontal sebesar 0,982 meter. Pada citra SPOT 6 terkoreksi metode polinomial orde 1 didapatkan akurasi horizotal 3,776 meter dan 3,621 meter 
pada citra terkoreksi metode polinomial orde 2 . Berdasarkan Tabel 4.15 yaitu kelayakan citra sebagai dasar untuk pembuatan peta desa, citra satelit Pleiades 1B memenuhi syarat pembuatan peta desa skala 1:2.500, 1:5.000 dan 1:10.000. Sedangkan pada citra SPOT 6 memenuhi syarat pembuatan peta desa skala 1: 10.000 .

\section{KESIMPULAN}

Berdasarkan hasil dan analisa yang telah diuraikan, maka kesimpulan yang didapatkan dari penelitian ketelitian geometrik citra satelit Pleiades 1B dan SPOT 6 ini, diantaranya:

- Pada citra Pleiades 1B dengan metode polinomial orde 1 didapatkan nilai RMS 0,322 pixel dan dengan metode polinomial orde 2 diperoleh nilai RMS 0,188 pixel. Sedangkan pada citra SPOT 6 dengan metode polinomial orde 1 didapatkan nilai RMS 0,634 pixel dan dengan metode polinomial orde 2 diperoleh nilai RMS 0,350 pixel.

- Berdasarkan uji ketelitian geometrik menggunakan titik-titik ICP, didapatkan nilai RMSE pada citra Pleiades 1B adalah 0,806 meter dan pada citra SPOT 6 adalah 2,489 meter pada citra hasil rektifikasi metode polinomial orde 1 . Sedangkan citra hasil rektifikasi metode polinomial orde 2 didapatkan nilai RMSE pada citra Pleiades 1B 0,647 meter dan 2,386 meter pada citra SPOT 6. Nilai RMSE pada citra Pleiades 1B lebih bagus daripada SPOT 6.

- Untuk kelayakan citra resolusi tinggi untuk pembuatan peta desa, citra satelit Pleiades 1B memenuhi syarat pembuatan peta desa dengan skala 1:2.500, 1:5.000, dan 1:10.000. Sedangkan pada citra satelit SPOT 6 memenuhi syarat untuk pembuatan peta desa dengan skala 1:10.000.

\section{DAFTAR PUSTAKA}

Afifi, Z., 2015. "Studi Pemetaan Fenomena Pemutihan Terumbu Karang (Coral Bleching) Menggunakan Citra Satelit Worldview-2 (Studi Kasus: Perairan PLTU, Probolinggo, Jawa Timur)". Institut Teknologi Sepuluh Nopember, Surabaya.

Anjasmara, I.M. 2005. "Hitung Kerangka Geodesi". Surabaya: Institut Teknologi Sepuluh Nopember.

BIG, 2016b. "Spesifikasi Teknis Penyajian Peta Desa".

Mohammed, N.Z. \& Eiman Eisa. 2013. "The Effect of Polynomial Order on Georeferencing Remote Sensing Images." International Journal of
Engineering and Innovative Technology (IJEIT), Vol 2(8), hal. 5-8

Putri, H.K., 2013. "Studi Deskriptif tentang Manfaat Sosial - Ekonomi Ekowisata Mangrove Wonorejo Bagi Masyarakat Kelurahan Wonorejo, Kecamatan Rungkut, Surabaya". Universitas Airlangga, Surabaya.

Rudianto, B., 2010. Analisis Ketelitian Objek pada Peta Citra Quickbird RS 0,68 m dan Ikonos RS 1,0 m. Jurnal Rekayasa, Institut Teknologi Nasional, Vol XIV(3). hal. 156-164. LPPM Itenas. Bandung

Sadarviana, V. et al., 2014. "Pembuatan Peta Desa Dalam Rangka (Desa Lembang Kecamatan Lembang Kabupaten Bandung Barat)". Laporan Pengabdian LPPM, Bandung: LPPM ITB.

Setiadi, Arfian dkk. Uji Ketelitian Hasil Rektifikasi Citra Quickbird engan Perangkat Lunak Global Mapper. Teknik Geodesi Universitas Diponegoro, Semarang

Yudha, I. S, 2015. Studi Jumlah dan Distribusi Titik Kontrol Tanah untuk Proses Rektifikasi Citra Resolusi Tinggi (Studi Kasus : Kota Kediri, Jawa Timur). Tugas Akhir. Surabaya: Jurusan Teknik Geomatika, Fakultas Teknik Sipil dan Perencanaan, Institut Teknologi Sepuluh Nopember 